Vol. 3, No. 2, Juli 2019, 10-29

Available Online at https://ejournal.warmadewa.ac.id/index.php/kulturistik DOI: dx.doi.org/10.22225/kulturistik.3.2.1185

\title{
ANALISIS KESANTUNAN BAHASA MEDIA SOSIAL: KOMUNIKASI MAHASISWA KEPADA DOSEN STMIK STIKOM INDONESIA
}

\author{
Agus Ari Iswara \\ STMIK STIKOM Indonesia \\ ari.iswara@stiki.indonesia.ac.id \\ Kadek Yogi Susana \\ STMIK STIKOM Indonesia \\ yogi.susana@stiki-indonesia.ac.id
}

\begin{abstract}
ABSTRAK
Fakta tahun 2018, mahasiswa dan dosen STMIK STIKOM Indonesia aktif berkomunikasi dan berinteraksi menggunakan media sosial dibandingkan menggunakan fitur pesan singkat (SMS). Penelitian ini bertujuan untuk menganalisis pola kesantunan tuturan mahasiswa, representasi penggunaan maksim kesantunan bahasa teks mahasiswa, dan bagaimana tingkat kesantunan mahasiswa dalam berinteraksi dengan dosen STMIK STIKOM Indonesia di media sosial. Data dalam penelitian ini adalah dokumentasi percakapan di media sosial antara mahasiswa dengan dosen pada semester genap tahun 2017/2018 dan semester ganjil 2018/2019 serta data bersumber dari kuesioner dan wawancara dengan dosen sebagai responden. Data dikaji menggunakan beberapa teori, yaitu teori kesantunan yang dikemukakan oleh Leech dan teori kesantunan Scollon serta mengaplikasikan skala Likert dan skala Guttman. Hasil dari analisis menunjukkan bahwa terdapat sepuluh (10) macam pola interaksi antara mahasiswa dengan dosen, yaitu: (1) penjelasan mengenai tugas perkuliahan, (2) konsultasi urusan kemahasiswaan, (3) permohonan ijin kehadiran dan kedatangan, (4) konfirmasi kehadiran dosen, (5) menginformasikan waktu kuliah, (6) memberitahukan nomor ponsel, (7) permintaan waktu bimbingan, (8) kuliah tambahan atau hari pengganti, (9) modul dan sarana belajar, (10) konfirmasi mengenai ujian. Maksim kesantunan yang digunakan dalam tuturannya, yaitu maksim kebijaksanaan dan maksim penerimaan. Sementara itu, terdapat tiga instrumen yang mempengaruhi kesantunan tuturan mahasiswa, yaitu (1) kekuasaan, (2) jarak sosial, dan (3) tingkat kepentingan. Selanjutnya, menurut dosen di lingkungan kampus, saat berkomunikasi, para mahasiswa menggunakan bahasa yang santun, akan tetapi mayoritas responden menyatakan diperlukan ketentuan yang mengatur tata cara mahasiswa mengirim pesan kepada dosen.
\end{abstract}

Kata kunci: bahasa, kesantunan, media sosial, mahasiswa, dosen

\begin{abstract}
[Title: Analysis of Language Politeness on Social Media: Communication of Student to Lecturer of STMIK STIKOM Indonesia] In 2018, both student and lecture of STMIK STIKOM Indonesia are more active in communicating and interacting on social media rather than use Short Message Service (SMS). This research aimed to do an analysis about scheme of student utterance politeness, representation use of politeness maxim in their text, and the level of their politeness in interact with their lecture through social
\end{abstract}


Vol. 3, No. 2, Juli 2019, 11

Available Online at https://ejournal.warmadewa.ac.id/index.php/kulturistik DOI: dx.doi.org/10.22225/kulturistik.3.2.1185

media. The data collected from documentation of their conversation on social media in two semesters of 2017 until 2018 and it is also collected from questioner and interview with the lecture as the respondent. The data analyzed by applied some theory. The main theory is the theory of politeness from Leech, continued by theory from Scollon, and then supported by Scale of Likert and Guttman. The Result shows that there are ten (10) schemes of interactions happen between student and lecture. They are (1) about assignment, (2) clarification about study, (3) permit of attendance, (4) confirming about lecture attendance, (5) informing about class schedule, (6) informing their contact, (7) confirming about guidance schedule, (8) additional class schedule, (9) module and learning tools, (10) confirming about test. It is found those politeness maxims used in their utterance are Tact Maxim and Generosity Maxim. The instruments that form their politeness are power, social distance, and weight of imposition. Furthermore, about the politeness level of student utterance based on interview with the lecture, it is found that they uses polite utterance, but most of the lecture said that the collage need to create regulation for controlling student in sending text through social media.

Keywords: language, politeness, social media, student, lecturer

\section{PENDAHULUAN}

Pada era digital, manusia sangat aktif berkomunikasi memalui media sosial yang menggeser penggunaan layanan pesan singkat atau Short Message Service (SMS). Efisiensi, kemudahan, dan berbagai fiturnya telah menggiring para pengguna untuk meninggalkan layanan SMS. Batasan jumlah karakter dan tingginya biaya kirim per SMS menimbulkan fenomena penggunaan kata-kata yang disingkat, hal itu dianggap sebuah hal yang lumrah sekalipun pesan tersebut dikirim kepada penerima yang memiliki status sosial lebih tinggi dari pengirimnya. Saat ini, sistem dan fitur media sosial tidak membatasi penggunanya dengan jumlah karakter dan memangkas mahalnya biaya pengiriman pesan, bahkan tidak hanya mengirim pesan berupa kata-kata, tapi juga pesan suara, foto, video, dokumen, dan yang teranyar dapat melakukan panggilan video serta mengunggah status. Inovasi ini mempengaruhi gaya komunikasi penggunanya tidak lagi harus menyingkat kata-kata seperti pada layanan SMS.

Inovasi pada media sosial menimbulkan paradigma adanya keharusan mengirim pesan dengan kata-kata yang santun kepada penerima yang dianggap memiliki status sosial yang lebih tinggi untuk menunjukkan rasa hormat dan penghargaan serta menghindari ketersinggungan. Kesantunan adalah bentuk perilaku yang disepakati dalam hubungan antara personal saling merasa ada kesesuaian dan memberikan sesuatu yang memiliki makna saling menghargai (Ngalim, 2013: 78). Berbahasa santun merupakan salah satu wujud perilaku berbahasa yang disepakati oleh komunitas penutur bahasa tertentu, dengan tujuan saling menghargai dan menghormati satu dengan yang lain, menghindari terjadi ketersinggungan, memperkecil potensi terjadi konflik. Hingga tahun 2018, belum ada kebijakan dari institusi yang mengatur etika mahasiswa mengirim pesan teks kepada dosen ditengah keakraban suasana kampus antara mahasiswa dan dosen yang diterapkan di STMIK STIKOM Indonesia. Oleh karena itu penulis melihat adanya kebutuhan untuk mengkaji lebih dalam masalah kesantunan tuturan mahasiswa sehingga penulis tertarik untuk menganalisis kesantunan bahasa mahasiswa kepada dosen STMIK STIKOM Indonesia di sosial media.

Penelitian mengenai kesantunan berbahasa telah dilakukan oleh beberapa peneliti, diantaranya Wardhono (2013) dalam penelitiannya yang berjudul $A n$ 
Vol. 3, No. 2, Juli 2019, 12

Available Online at https://ejournal.warmadewa.ac.id/index.php/kulturistik DOI: dx.doi.org/10.22225/kulturistik.3.2.1185

Analysis On Politenesss In SMS Of The Students To The Lecturers Of English Department UNIROW Tuban. Selanjutnya, Tretyakova (2016) dalam penelitiannya berjudul On Politeness in Translation. Berikutnya, Imanuel Kamlasi (2017) dengan penelitiannya berjudul The Positive Politeness in Conversations Performed by the Students of English Study Program of Timor University. Selain itu, Fitriah \& Hidayat (2018) juga menulis Politeness: Cultural Dimensions Of Linguistic Choice. Selanjutnya, Budiarta \& Rajistha (2018) melakukan penelitian dengan judul Politemess In "Adit dan Sopo Jarwo" Animation. Yang terbaru, penelitian oleh Murni Mahmud (2019) berjudul The use of politeness strategies in the classroom context by English university students. Penelitian-penelitian tersebut menjadi referensi dari penelitian ini.

Teori utama yang digunakan dalam penelitian ini adalah teori pragmatik yang dikemukakan oleh Leech. Dalam The Principles of Pragmatics dia mengemukakan, untuk menyatakan sebuah tuturan santun atau tidak terdapat enam macam maksim kesantunan (Oka, 2011: 206-207), keenam maksim tersebut yaitu (1) Maksim Kebijaksanaan (Tact Maxim), (2) Maksim Kedermawanan (Generosity Maxim), (3) Maksim Penghargaan (Approbation Maxim), (4) Maksim Kesederhanaan (Modesty Maxim), (5) Maksim Permufakatan (Agreement Maxim), (6) Maksim Kesimpatisan (Sympath Maxim). Secara lebih rinci diuraikan seperti berikut:

\section{A. Maksim Kebijaksanaan}

Dalam prinsip kesantunan, maksim ini mempengaruhi penutur untuk secara sengaja mengurangi keuntungan pada dirinya dan memaksimalkan keuntungan mitra tuturnya sehingga seolah-olah pihak penutur memposisikan mitra tutur lebih tinggi. Maksim ini mengupayakan untuk mengurangi atau memperkecil kerugian kepada orang lain dan menambah atau memperbesar keuntungan kepada pihak lain. Lebih spesifik penggunaan maksim ini dengan menghindarkan sikap dengki, iri hati, dan sikap-sikap lain yang kurang santun terhadap mitra tutur.

\section{B. Maksim Kedermawanan}

Maksim ini disebut juga maksim kemurahan hati. Para peserta pertuturan diharapkan dapat menghormati pihak lain. Penghormatan kepada orang lain dianggap akan terjadi apabila orang dapat mengurangi keuntungan bagi dirinya sendiri dan memaksimalkan keuntungan bagi pihak lain. Dengan kata lain maksim ini mengupayakan untuk mengurangi keuntungan dan menambah pengorbanan kepada diri sendiri. Ketika tuturan tidak sesuai atau berlawanan dengan konsep tersebut, maka tuturan dianggap berkurang kesantunannya khususnya dalam aspek kedermawanan.

\section{Maksim Penghargaan}

Dalam maksim penghargaan dijelaskan bahwa tuturan akan dianggap santun apabila selalu berusaha memberikan penghargaan kepada pihak lain. Dengan maksim ini, diharapkan agar para peserta pertuturan tidak saling mengejek, saling mencaci, atau saling merendahkan. Lebih spesifik maksim ini mengupayakan untuk mengurangi kecaman kepada pihak lain dan menambah pujian pada pihak lain. Ketika tuturan tidak sesuai atau berlawanan dengan konsep tersebut, maka tuturan dianggap kurang santun dalam aspek penghargaan. 
Vol. 3, No. 2, Juli 2019, 13

Available Online at https://ejournal.warmadewa.ac.id/index.php/kulturistik DOI: dx.doi.org/10.22225/kulturistik.3.2.1185

\section{Maksim Kesederhanaan}

Dalam maksim kesederhanaan atau maksim kerendahan hati, peserta tutur diharapkan dapat bersikap rendah hati dengan cara mengurangi pujian terhadap dirinya sendiri. Lebih spesifik maksim ini mengupayakan untuk mengurangi pujian pada diri sendiri dan menambah kritik pada diri sendiri. Ketika tuturan tidak sesuai atau berlawanan dengan konsep tersebut, maka tuturan dianggap kurang santun khususnya dalam aspek kesederhanaan.

\section{E. Maksim Permufakatan}

Maksim permufakatan atau kesepakatan disebut juga dengan maksim kecocokan. Maksim ini menekankan agar para peserta tutur saling membina kecocokan atau kemufakatan dalam membangun tuturan. Apabila terdapat kemufakatan atau kecocokan antar penutur dalam kegiatan bertutur, maka masingmasing dapat dikatakan bertutur santun. Maksim ini mengupayakan peserta tutur untuk mengurangi ketidaksesuaian pada diri sendiri dengan pihak lain dan meningkatkan persesuaian antar diri sendiri dengan pihak lain.

\section{F. Maksim Kesimpatisan}

Dalam maksim kesimpatisan, diharapkan agar para peserta tutur dapat memaksimalkan sikap simpati antara pihak yang satu dengan pihak lainnya. Sikap antipati terhadap salah seorang peserta tutur akan dianggap sebagai tindakan tidak santun. Maksim ini mengupayakan untuk mengurangi antipati antara satu pihak dengan pihak lain dan memperbesar simpati antar pihak.

Teori selanjutnya adalah teori kesantunan yang dikemukakan Scollon yang menyatakan ada tiga faktor yang mempengaruhi kesantunan ujaran, yaitu (1) Kekuasaan (power) yang artinya terdapat kecenderungan menaikkan tingkat kesantunan ujaran terhadap mitra tutur yang memiliki kekuasaan lebih tinggi dari penutur. (2) Jarak sosial (social distance) artinya semakin dekat atau akrab hubungan seseorang, semakin rendah tingkat kesantunan yang digunakan. Sebaliknya, semakin jauh kedekatan sebuah hubungan, semakin tinggi tingkat kesantunan yang digunakan. (3) Tingkat kepentingan (weight of imposition) artinya semakin tinggi tingkat kepentingan, maka semakin tidak langsung ujarannya (Scollon, 1995). Sejalan dengan teori tersebut, Amir juga menyatakan bahwa penutur bahasa Indonesia juga menggunakan parameter-parameter tersebut untuk memilih jenis kesantunan dan tingkat kesantunan dalam tuturan (Amir, 2004).

Sementara itu, dalam menentukan skala kesantunan tuturan mahasiswa kepada dosen di media sosial, penulis mengaplikasikan Skala Likert. Skala ini digunakan untuk mengukur sikap, pendapat, serta persepsi tentang fenomena sosial. Dengan skala ini variabel yang akan diukur dijabarkan menjadi indikator variable. Selanjutnya, indikator dijadikan sebagai titik tolak untuk menyusun item -item instrumen yang dapat berupa pernyataan atau pertanyaan. Jawaban setiap item intrumen yang menggunakan skala ini mempunyai gradasi dari sangat negatif sampai sangat positif, yang dapat berupa skor (1) sampai (5), yaitu (1) sangat tidak santun, (2) tidak santun, (3) sedang, (2) santun (1) sangat santun. Selanjutnya, untuk mengetahui perlu atau tidaknya pihak kampus membuat ketentuan yang mengatur tata cara mahasiswa berkomunikasi kepada dosen di media sosial, penulis mengaplikasikan Skala Guttman sehingga didapat jawaban 
Vol. 3, No. 2, Juli 2019, 14

Available Online at https://ejournal.warmadewa.ac.id/index.php/kulturistik DOI: dx.doi.org/10.22225/kulturistik.3.2.1185

yang tegas dan hasil yang jelas dengan menyediakan hanya dua alternatif jawaban, yaitu "ya-tidak", "benar-salah"; "positif-negatif"; "pernah-tidak pernah". Data yang didapat berupa data interval atau rasio dikotomi.

\section{METODE}

Penelitian ini merupakan penelitian kualitatif kuantitatif yang dipadukan dengan menggunakan pendekatan pragmatik. Penelitian kualitatif berusaha memahami makna dari fenomena-fenomena, peristiwa-peristiwa dan keterkaitannya dengan orang-orang atau masyarakat yang diteliti dalam konteks kehidupan dalam situasi yang sebenarnya. Realita dalam sebuah karya terbentuk secara simultan sehingga tidak dapat dipisahkan antara sebab dengan akibat. Data hanya bisa dimengerti berdasarkan konteks (Sutopo, 2006: 29).

Data dalam penelitian ini berupa bahasa tulis yang mengandung maksimmaksim kesantunan yang dukemukakan oleh Leech. Data tersebut dikumpulkan dari berbagai narasumber, yaitu dosen-dosen di STMIK STIKOM Indonesia yang aktif berkomunikasi lewat media sosial dengan mahasiswa. Data dikumpulkan dengan teknik wawancara, dengan menjawab kuisioner pada semester genap tahun 2018. Kemudian, dokumentasi percakapan dosen-dosen dengan mahasiswa di media sosial.

Analisis data dilakukan dengan teknik interaktif, dengan cara reduksi data, penyajian data, dan penarikan simpulan. Pertama, reduksi data merupakan tahap seleksi data secara terperinci. Kedua, penyajian data-data yang sudah ditetapkan kemudian disusun secara teratur berdasarkan rumusan. Terakhir, penarikan simpulan dimana peneliti dapat menarik simpulan mengenai bahasa tulis yang sesuai dengan maksim kesantunan dan bahasa tulis yang melanggar maksim kesantunan berbahasa.

Teknik pengumpulan data yang diaplilkasikan dakam penelitian ini adalah dengan teknik kuesioner dan dokumentasi. Teknik kuesioner digunakan untuk memperoleh data untuk mengitung skala kesantunan tuturan mahasiswa berdasarkan skor yang diberikan oleh para dosen sebagai responden. Bersamaan saat menerapkan teknik kuesioner, penulis juga menerapkan teknik dokumentasi dengan cara minta ijin para dosen yang bersedia memberikan dokumentasi percakapannya di media sosial dengan mahasiswa selama dua semester terakhir. Dokumentasi percakapan tersebut digunakan untuk memperoleh data pola kesantunan tuturan serta maksim kesantunan dalam tuturan yang digunakan.

Analisis data penelitian ini disajikan melalui proses triangulasi data meliputi tiga tahap, yaitu verifikasi data, penyajian data, dan klasifikasi data. Pertama verifikasi atau peninjauan ulang terhadap data yang diperoleh. Selanjutnya data disajikan dan diklasifikasikan berdasarkan kategori-kategori yang telah ditentukan oleh peneliti. Setelah tahap tersebut, peneliti dapat menarik simpulan mengenai rumusan masalah dalam penelitian ini. Teknik analisis yang diaplikasikan adalah teknik referensial dan inferensial. Teknik referensial diaplikasikan untuk menunjukkan kesesuaian konsep yang terdapat dalam tuturan dengan konsep yang terdapat dalam maksim-maksim kesantunan. Sementara itu, teknik inferensial digunakan untuk menginferensikan maksud yang terkandung dalam data. 
Vol. 3, No. 2, Juli 2019, 15

Available Online at https://ejournal.warmadewa.ac.id/index.php/kulturistik DOI: dx.doi.org/10.22225/kulturistik.3.2.1185

\section{PEMBAHASAN \\ POLA KESANTUNAN BAHASA}

Pada Bab ini dikemukakan hasil penelitian mengenai pola kesantunan bahasa teks percakapan di media sosial antara mahasiswa kepada dosen di STMIK STIKOM Indonesia Denpasar. Berdasarkan analisis terhadap konten percakapannya, ditemukan bahwa 50 teks percakapan tersebut memiliki hubungan yang erat dengan kegiatan perkuliahan dan kehidupan kampus. Isi teks percakapan tersebut dikategorikan ke dalam sepuluh (10) macam, yaitu: (1) penjelasan mengenai tugas perkuliahan, (2) konsultasi urusan kemahasiswaan, (3) permohonan ijin kehadiran dan kedatangan, (4) konfirmasi kehadiran dosen, (5) menginformasikan waktu kuliah, (6) memberitahukan nomor ponsel, (7) permintaan waktu bimbingan, (8) kuliah tambahan atau hari pengganti, (9) modul dan sarana belajar, (10) konfirmasi mengenai ujian.

\section{Penjelasan mengenai tugas perkuliahan}

Berdasarkan analisis data, diperoleh hasil bahwa posisi pertama, jumlah percakapan yang paling dominan adalah mahasiswa minta penjelasan mengenai tugas perkuliahan yang diberikan oleh dosen. Percakapan ini menempati urutan pertama karena dari 50 percakapan, sebanyak 17 percakapan atau $34 \%$ yang isinya meminta penjelasan mengenai tugas. Perhatikan data berikut!

a. "Selamat malam bu, mohon maaf mengganggu. Saya Putu Agus Adi Widnyana dari kelas K pagi, jurusan TI-DGM. Mau nanya bu soal tugasnya dijilid warna apa ya bu?".

b. "Selamat sore pak, saya yogi korti kelas s pagi, mau menanyakan tentang tugas algorithm yg dikumpul di edmodo, tugas saya tetap bermasalah pak untuk batas waktu pengumuman kapan ya pak? Terimakasih.".

c. "Selamat malam bu. Ini saya korti kelas K. Maaf bu, teman2 bertanya untuk spasi makalahnya itu kan 1.0 atau $1 \mathrm{~cm}$ bu? Terimakasi".

d. "Selamat malam buk, maaf mengganggu istirahatnya. Sya Sari Noviana dari kelas I. Untuk tugasnya bukan buat makalah, tapi harus ada covernya bu?? Terima kasih sebelumnya.".

e. "Buk ini ilham kelas $J$ mw brtanya jelaskan mengenai gambaran umum dri suatu bisnis? Sertakan dengan contohnya! Maksud dri contohnya itu contoh bisnis usahanya yah buk? Maaf mengganggu”.

f. "Selamat siang pak, maaf mengganggu, sya Gusti Nyoman Oka Wirawan nim 16101469 mau informasikan bahwa sya sudah mengumpulkan tugas 1 pem.web II di grup edmodo

Trims".

g. "Selamat sore pak, maaf mengganggu. Saya Siti, mahasiswi bapak di kelas $S$. Terkait tentang tugas yang di edmodo. Tugas 3 nya tentang apa ya pak? Minggu lalu seingat saya, bapak tidak ada memberikan tugas. ".

h. "Selamat pagi pak maaf mengganggu, saya rina Novita Yanti kelas Z ti kab malam, minta tolong accept permintaan Edmodo sya, agar bisa untuk mengirim tugas, terima kasih".

i. "Om swastiastu, selamat sore Pak Gandika

Saya mahasiswa stiki angkatan 2016

Nama : Putu Putri Yandayani

Nim : 16101022 
Vol. 3, No. 2, Juli 2019, 16

Available Online at https://ejournal.warmadewa.ac.id/index.php/kulturistik

DOI: dx.doi.org/10.22225/kulturistik.3.2.1185

Prodi : Ti-kab

Semester : 5

Saya mau bertanya, untuk tugas web ii terakhir dikumpul kapan pak?

Tolong diinfokan...

Terimakasih,

Selamat sore.".

j. "Selamat Sore Pak .. Maaf mengganggu waktu nya sebentar. Saya Rina Januwarti NIM : 17101362 Kelas Z malam Perkuliahan OOP .. Saya mau tanya terkait tugas yang diberikan pertemuan kemarin pak. Untuk soal No.1 yaitu menampilkan Bilang genap dengan menginputkan nilai 10 dan output 2,4,6,8,10 jadi nilai dari yang terkecil ke yang terbesar. Saya sudah coba buat tapi project yang saya buat jika menginputkan nilai 10 outputnya 10,8,6, 4,2 jadi nilai yang terbesar sampai yang terkecil pak, dan saya sudah coba search di google cara untuk menampilkan bilangan genap dari nilai yang terkecil ke yang besar jika inputannya adalah nilai yang paling besar tidak ada pak.. Jadi cara memperoleh nya kira kira gimana ya pak ?Karena saya cari solusi lain harus menggunakan array untuk mengurutkan dari nilai dari yang terkecil sampai yang terbesar."

k. "Assalamualaikum pak,maaf mengganggu,saya mau tanya pak mengenai tugas interview pedagang,itu termasuk dalam fungsi permintaan pak? terimakasih,".

1. "Selamat pagi bu, saya Eka Surya anak didiknya ibu di kelas MTI C, saya ingin bertanya bu apa benar tugas softskill saya sudah terkirim bu?".

m. "Selamat Malam pak!

Maaf saya ganggu waktunya, saya Noly Ermi Damayanti dari kelas I.

Saya mau nanya pak, tugas B.Inggris saya via Email sudah bapak terima atau belum? Karena saya tidak menemukan email bapak".

n. "Halo pak selamat siang maaf mengganggu saya wahyu prahyangan dari kelas i prodi ti dgm. ada yang mau saya tanyakan mengenai tugasnya pak, apa bapak ada waktu hari ini?

Yang tugas buat vidio percakapan minimal 10 menitnya pak

Itu tugasnya boleh di buat seperti film pendek pak?".

"tugas nya perlu dikirim k email ibuk juga? apa print aja?".

\section{Konsultasi perihal kemahasiswaan}

Pada urutan kedua, jumlah percakapan yang menyusul adalah pertanyaanpertanyaan seputar kemahasiswaan seperti penyusunan Kartu Rencana Studi, dan lain-lain. Jumlah yang diperoleh adalah sebanyak 11 percakapan atau $22 \%$. Perhatikan data berikut!

a. "validasi tracer studynya harus di print pak ato boleh softcopy ??".

b. "hari Jum'at yg muslim Jum'atan, pelaksanaan wisuda mulai pukul berapa pak?".

c. "Kalau untuk pengambilan kontribusi bagian pengambilan toga misal tidak muat toga nya bagaimana pak wahyu Wijaya?".

d. "Maaf pak saya mau tanya untuk undangan untuk wisuda dibagikannya kapan ya pak? Wahyu Wijaya".

e. "Pas gladi pke baju ap? apa sama kyak yudisium?".

f. "Kapan di laksanakannya kk makasih...". 
Vol. 3, No. 2, Juli 2019, 17

Available Online at https://ejournal.warmadewa.ac.id/index.php/kulturistik DOI: dx.doi.org/10.22225/kulturistik.3.2.1185

g. "Maaf, apakah prestasi sebelum menjadi mahasiswa STIKI boleh diajukan juga? Klo piagam putra Putri kampusnya sma truna truni kmpus bisa buk?”.

h. "Pak pengecekannya kami yang bawa berkasnya langsung ke aula.?? Infonya masih ambigu pak.??”.

i. "Pilih salah satu tanggal nya atau harus dua kali dtg pak? Itu harus dateng jam 14.00 pak?

j. "Pak Wahyu Wijaya Saya ada kerja diluar kota dari tgl 3 sampai tgl pak dan tgl 8 oktober baru balik kebali. Apakah ada kebijakan ?".

k. "Buk saya bisanya besok kumpul, soalnya dikasih pinjem jasnya besok gmn buk?? Weiwei Wei".

1. "Halu bu ini saya mau upload foto dri tadi gk bisa gimana donk?? Padahal saya sudah di coba terus... ukuran nya juga 1 mb tpi tetep aja gk mau buu...".

m. "Mohon maaf pak, saya mau nanya,, setelah bimbingan di siperi apa harus ke kampus lagi buat minta persetujuan dosen pembimbing seperti yg semester lalu?".

"setiap kali saya update nomor telp d siperi selalu kembali lagi ke nomor yg lama , gmana pak?”.

\section{Permohonan ijin kehadiran dan kedatangan}

Di posisi ketiga, alasan selanjutnya mahasiswa melakukan interaksi lewat media sosial kepada dosen adalah untuk menyampaikan permohonan ijin tidak dapat mengikuti perkuliahan karena alasan tertentu atau adanya halangan yang menyebabkann mereka terlambat tiba di kelas. Dari data diperoleh sebanyak 5 percakapan atau $10 \%$. Perhatikan data berikut!

a. "Selamat siang bu, saya I Gede Ananda Dwi Saputra dengan Nim 18101198 Kelas D, nnti saya dapat mata kuliah ibu pada jam 12.20 kan bu, saya ijin agak telat bu, soalnya masih ada kegiatan upacara agama dirumah butrimakasih bu..”.

b. "Sore pak, maaf sya tdk bisa hadir di teorinya, dkarenakan sya bru plang krja pak apa boleh sya hadir pas praktikumnya sja pak?".

c. Selamat pagi pak, saya I Gusti Ngurah Meiga Arya dari Kelas D, pak saya mau minta ijin tidak hadir saat matakuliah bapak karena saya ada upacara potong gigi pak, terima kasih pak selamat pagi"

d. "Selamat siang ibuk, aku ngak bisa ikut pelajan ibuk aku lagi ngak enak badan ibuk, aku mintak ijin boleh buk .

Nama: Dodik saputra

Nim : 18101156

Mohon maaf buk sekali lagi boleh nggak buk”.

"selamat pagi pak maaf mengganggu saya ni ketut triska ningsih nim 16101081 izin hari ini pak saya ada upacara

terimakasih pak....”.

\section{Konfirmasi kehadiran dosen}

Selanjutnya di posisi kelima, mahasiswa berkomunikasi lewat media sosial dengan dosen dengan tujuan untuk memastikan apakah dosen akan mengisi perkuliahan di kelas atau tidak pada hari dan jam tertentu. Didapatkan sebanyak 4 percakapan atau $8 \%$. Perhatikan data berikut!

a. "Pak agus, hari ini mengajar?Saya dedy dari kelas sistem komputer c pak". 
Vol. 3, No. 2, Juli 2019, 18

Available Online at https://ejournal.warmadewa.ac.id/index.php/kulturistik DOI: dx.doi.org/10.22225/kulturistik.3.2.1185

b. "Selamat sore, Pak agus, hari ini mengajar? Saya dedy dari siskom kelas C".

c. "Selamat pagi pak

Bapak nnti bahasa inggris IV jam 10.50, masuk mengajar atau tidak pak? Terima kasih".

d. "Maaf pak, mau nanya, besok pak ada jam di kampus gak?".

\section{Memberitahukan nomor ponsel}

Mahasiswa mengirim pesan dengan isi memberitahukan nomor ponsel pada umumnya dilakukan oleh kordinator kelas kepada dosen agar dosen dapat menyimpan nomor tersebut pada kontaknya. Jumlah yang sama ditemukan seperti poin (5), yaitu sebanyak 3 percakapan atau $6 \%$ dari 50 percakapan. Perhatikan data berikut!

a. "Selamat sore pak agus, saya dedy martawan dari koor SK C pagi, terima kasih".

b. "Selamat sore bapak saya korti dari kelas $G$ teknologi informasi pariwisata Terima kasih".

c. Selamat sore pak, saya risky.. jurusan sistem komputer dari mata kuliah bahasa inggris.

Saya mau memberi tahu pak, saya Korti dari mata kuliah bahasa inggris

Terimakasih..".

\section{Modul dan sarana belajar}

Penjelasan mengenai materi bahan ajar dan sarana belajar menempati urutan kesembilan dengan jumlah sebanyak 3 percakapan atau sebesar $6 \%$ dari total 50 percakapan. Perhatikan data berikut!

a. "Selamat malam pak

Maaf mengganggu waktunya

Saya mahasiswa angkatan 2017

Nama : Haritcha

Nim: 17101849

Saya mahasiswa yang mengikuti kelas pemrograman web 2 di kelas bapak. Apakah saya bisa minta kode grub di edmodo pak?

Terimakasih".

b. "Slmt mlm ibu,,ini sama Ambrosius Sapu,, Nim:18101162

Sy mau nanya nc,,pasword edmodo brapa ya Bu..?".

c. "Selamat sore bu, maaf mengganggu Saya Suar mahasiswa kelas B Kewirausahaan hari Selasa. Saya blm masuk group wa sama edmono bu, saya mau minta kode edmodonya bu. Terimakasih"

\section{Permintaan waktu bimbingan}

Pada poin ini ditemukan sebanyak 2 percakapan atau $4 \%$ dari keseluruhan percakapan berisi permintaan mahasiswa untuk dapat bertemu dan melakukan bimbingan, kapan dan dimana mahasiswa dapat bertemu dengan dosen pembimbingnya. Perhatikan data berikut!

a. "Selamat sore pak

Hari ini bapak ada di kampus?

Saya mau bimbingan web nya pk". 
Vol. 3, No. 2, Juli 2019, 19

Available Online at https://ejournal.warmadewa.ac.id/index.php/kulturistik DOI: dx.doi.org/10.22225/kulturistik.3.2.1185

b. "selamat siang pak., saya Palgunayoga mahasiswa stiki untuk hari ini bapak ada di kampus? saya mau bimbingan seminar pak".

Kuliah tambahan atau hari pengganti

Hasil temuan juga menunjukkan mahasiswa menggunakan layanan pesan media sosial untuk berkomunikasi dengan dosen dalam menentukan jadwal kuliah tambahan atau hari pengganti. Dari hasil analisis data, terdapat sebanyak 2 percakapan atau $4 \%$ berisi tentang perihal tersebut. Perhatikan data berikut!

"Sabtu bisa diadakan kuliah tambahan untuk pengganti pak? Tmen tmen mintanya sabtu".

"Selamat sore pak, bapak ada di kampus hari ini? maunya ngisi jam kosong pak untuk kelas pengganti.”.

\section{Menginformasikan waktu kuliah}

Yang dimaksud dengan menginformasikan waktu kuliah adalah mahasiswa mengingatkan dosen dengan mengirimkan pesan lewat media sosial bahwa perkuliahan sudah bisa dimulai sesuai dengan jadwal dan semua atau sebagian besar mahasiswa sudah berada di dalam kelas. Terdapat sebanyak 1 percakapan atau $2 \%$. Perhatikan data berikut!

"Selamat sore pak, saya sintha korti kelas $R$, hari ini ada kelas jam 15.40 pak. Kami smua sudah di ruangan 202”.

\section{Konfirmasi mengenai ujian}

Posisi terakhir diisi oleh pertanyaan-pertanyaan mahasiswa mengenai informasi jadwal ujian. Dari semua data yang terkumpul, hanya ditemukan 1 percakapan atau $2 \%$ mengenai hal tersebut. Perhatikan data berikut!

"Selamat malam buk, saya ni putu indah risma dewi dari matakuliah aplikasi akuntansi kelas B. Saya mau tanya untuk nyusul uasnya kapan ya buk?".

\section{KESANTUNAN BERBAHASA}

Berdasarkan analisis terhadap teks pesan mahasiswa kepada dosen, konteks tuturan yang terjadi antara mahasiswa kepada dosen sangat mempengaruhi maksim kesantunan yang digunakan dalam proses komunikasi. Mereka cenderung memilih dan menyampaikan tuturan yang lebih santun. Hal ini karena perbedaan usia, status atau derajat, dan perbedaan power antara kedua pihak tersebut. Kesantunan yang dimaksud disini adalah pemilihan dan penggunaan bahasa yang baik dan halus yang dipilih oleh mahasiswa dalam berkomunikasi kepada dosen melalui media sosial. Jika dikaitkan dengan teori Leech, dari keenam maksim yang ada ditemukan bahwa mahasiswa STMIK STIKOM Indonesia cenderung menggunakan Maksim Kebijaksanaan dan Maksim Kedermawanan/Penerimaan dalam tuturannya.

\section{Maksim Kebijaksanaan}

Menurut Leech maksim kebijaksanaan diungkapkan dengan tuturan impositif dan komisif. Maksim ini menggariskan setiap peserta pertuturan untuk meminimalkan kerugian orang lain atau memaksimalkan keuntungan bagi orang lain. Lebih jelas mengenai temuan tersebut, berikut ini diuraikan kesantunan berbahasa yang dimunculkan dalam tuturan. Perhatikan data berikut! 
a. "Selamat sore pak

Hari ini bapak ada di kampus?

Saya mau bimbingan web nya pk".

b. "selamat siang pak., saya Palgunayoga mahasiswa stiki untuk hari ini bapak ada di kampus?

c. "Sabtu bisa diadakan kuliah tambahan untuk pengganti pak? Tmen tmen mintanya sabtu".

d. "Sore pak, maaf sya tdk bisa hadir di teorinya, dkarenakan sya bru plang krja pak apa boleh sya hadir pas praktikumnya sja pak?".

e. "Halo pak selamat siang maaf mengganggu saya wahyu prahyangan dari kelas i prodi ti dgm. ada yang mau saya tanyakan mengenai tugasnya pak, apa bapak ada waktu hari ini?

Yang tugas buat vidio percakapan minimal 10 menitnya pak

Itu tugasnya boleh di buat seperti film pendek pak?".

f. "Selamat malam bu, mohon maaf mengganggu. Saya Putu Agus Adi Widnyana dari kelas K pagi, jurusan TI-DGM. Mau nanya bu soal tugasnya dijilid warna apa ya bu?".

g. "Selamat malam bu. Ini saya korti kelas K. Maaf bu, teman2 bertanya untuk spasi makalahnya itu kan 1.0 atau $1 \mathrm{~cm}$ bu? Terimakasi".

h. "Buk ini ilham kelas $J$ mw brtanya jelaskan mengenai gambaran umum dri suatu bisnis? Sertakan dengan contohnya! Maksud dri contohnya itu contoh bisnis usahanya yah buk? Maaf mengganggu".

i. "Selamat siang pak, maaf mengganggu, sya Gusti Nyoman Oka Wirawan nim 16101469 mau informasikan bahwa sya sudah mengumpulkan tugas 1 pem.web II di grup edmodo

Trims".

j. "Selamat pagi pak maaf mengganggu, saya rina Novita Yanti kelas Z ti kab malam, minta tolong accept permintaan Edmodo sya, agar bisa untuk mengirim tugas, terima kasih".

k. "Selamat siang bu, saya I Gede Ananda Dwi Saputra dengan Nim 18101198 Kelas D, nnti saya dapat mata kuliah ibu pada jam $12.20 \mathrm{kan}$ bu, saya ijin agak telat bu, soalnya masih ada kegiatan upacara agama dirumah butrimakasih bu..".

1. "Selamat pagi pak, saya I Gusti Ngurah Meiga Arya dari Kelas D, pak saya mau minta ijin tidak hadir saat matakuliah bapak karena saya ada upacara potong gigi pak, terima kasih pak selamat pagi"

m. "selamat pagi pak maaf mengganggu saya ni ketut triska ningsih nim 16101081 izin hari ini pak saya ada upacara terimakasih pak....".

n. "Selamat sore pak, saya risky.. jurusan sistem komputer dari mata kuliah bahasa inggris.

Saya mau memberi tahu pak, saya Korti dari mata kuliah bahasa inggris Terimakasih..".

o. "Selamat malam pak

Maaf mengganggu waktunya

Saya mahasiswa angkatan 2017

Nama : Haritcha

Nim: 17101849 
Vol. 3, No. 2, Juli 2019, 21

Available Online at https://ejournal.warmadewa.ac.id/index.php/kulturistik DOI: dx.doi.org/10.22225/kulturistik.3.2.1185

Saya mahasiswa yang mengikuti kelas pemrograman web 2 di kelas bapak. Apakah saya bisa minta kode grub di edmodo pak?

Terimakasih".

p. "Slmt mlm ibu,,ini sama Ambrosius Sapu,, Nim:18101162

Sy mau nanya nc,,pasword edmodo brapa ya Bu..?".

q. "Selamat sore bu, maaf mengganggu Saya Suar mahasiswa kelas B Kewirausahaan hari Selasa. Saya blm masuk group wa sama edmono bu, saya mau minta kode edmodonya bu. Terimakasih".

Pada data (a), dapat dilihat penggunaan maksim kebijaksanaan yang menunjukkan keinginan mahasiswa untuk meminta waktu untuk bimbingan tergantung pada ketersediaan waktu dosen pada teks “... Hari ini bapak ada di kampus? Saya mau bimbingan ...". Pada data (b) dapat dilihat pada teks “... untuk hari ini bapak ada di kampus ? ..." tuturan ini terjadi pada konteks mahasiswa memastikan kehadiran dosen sebelum minta waktu untuk bertemu. Pada data (c), "Sabtu bisa diadakan kuliah tambahan untuk pengganti pak? ..." juga menunjukkan keinginan mahasiswa untuk melaksanakan kuliah tambahan dengan memastikan ketersediaan dari dosen. Pada data (d), “... apa boleh sya hadir pas praktikumnya sja pak?" Dengan tuturan ini, sebenarnya (M) berupaya meminimalkan kerugian (D) dan sebaliknya memaksimalkan kerugian diri-nya sendiri.

\section{Maksim Kedermawanan/Penerimaan}

Sama seperti maksim kebijaksanaan, maksim ini juga diutarakan dengan kalimat komisif dan impositif. Maksim ini mewajibkan setiap peserta tindak tutur untuk memaksimalkan kerugian bagi diri sendiri dan meminimalkan keuntungan diri sendiri. Perhatikan data berikut!

M: Selamat sore pak, saya yogi korti kelas s pagi, mau menanyakan tentang tugasalgorithm yg dikumpul di edmodo, tugas saya tetap bermasalah pak untuk batas waktu pengumuman kapan ya pak? Terimakasih.".

D: Udah lwt dik

M: Okpak

Pada data tersebut dapat dilihat penggunaan maksim penerimaan oleh (M) dimana dia menerima resiko dari keterlambatannya dengan hanya menjawab "Ok pak". (M) tidak melakukan negosiasi lebih lanjut untuk mencapai kepentingannya. Tujuannya adalah untuk menghindari timbulnya konflik yang lebih besar yang akan mengganggu kepentingannya yang lain.

Dalam teorinya, Leech menyatakan juga bahwa bentuk kalimat tuturan yang digunakan juga menunjukkan adanya nilai kesantunan yang ingin dibangun dalam proses berkomunikasi. Pada konteks ini, semakin panjang tuturan yang digunakan oleh penutur maka semakin besar juga keinginannya untuk bertutur santun kepada mitra tuturnya. Lebih jelas dapat dilihat pada data berikut:

a. "Om swastiastu, selamat sore Pak Gandika

Saya mahasiswa stiki angkatan 2016

Nama : Putu Putri Yandayani

Nim : 16101022

Prodi : Ti-kab 
Vol. 3, No. 2, Juli 2019, 22

Available Online at https://ejournal.warmadewa.ac.id/index.php/kulturistik DOI: dx.doi.org/10.22225/kulturistik.3.2.1185

Semester : 5

Saya mau bertanya, untuk tugas web ii terakhir dikumpul kapan pak?

Tolong diinfokan...

Terimakasih,

Selamat sore.".

b. "Selamat Sore Pak .. Maaf mengganggu waktu nya sebentar. Saya Rina Januwarti NIM : 17101362 Kelas Z malam Perkuliahan OOP .. Saya mau tanya terkait tugas yang diberikan pertemuan kemarin pak. Untuk soal No.1 yaitu menampilkan Bilang genap dengan menginputkan nilai 10 dan output 2,4,6,8,10 jadi nilai dari yang terkecil ke yang terbesar. Saya sudah coba buat tapi project yang saya buat jika menginputkan nilai 10 outputnya 10,8,6,4,2 jadi nilai yang terbesar sampai yang terkecil pak, dan saya sudah coba search di google cara untuk menampilkan bilangan genap dari nilai yang terkecil ke yang besar jika inputannya adalah nilai yang paling besar tidak ada pak.. Jadi cara memperoleh nya kira kira gimana ya pak ?Karena saya cari solusi lain harus menggunakan array untuk mengurutkan dari nilai dari yang terkecil sampai yang terbesar."

c. "Halo pak selamat siang maaf mengganggu saya wahyu prahyangan dari kelas i prodi ti dgm. ada yang mau saya tanyakan mengenai tugasnya pak, apa bapak ada waktu hari ini?

Yang tugas buat vidio percakapan minimal 10 menitnya pak

Itu tugasnya boleh di buat seperti film pendek pak?".

d. "Selamat malam pak

Maaf mengganggu waktunya

Saya mahasiswa angkatan 2017

Nama : Haritcha

Nim: 17101849

Saya mahasiswa yang mengikuti kelas pemrograman web 2 di kelas bapak. Apakah saya bisa minta kode grub di edmodo pak?

Terimakasih”.

Pada keempat tuturan tersebut, mahasiswa berusaha untuk sangat santun dan menyampaikan tuturan selengkap mungkin dengan kalimat yang cukup panjang, dimulai dari mengucapkan salam, memperkenalkan diri, menyampaikan maksud atau pertanyaan, dengan meminimalkan penyingkatan kata. Akan tetapi, pada tuturan tertentu dalam data ditemukan bahwa beberapa dosen merespon dan menjawab tuturan mahasiswa tidak dengan teks yang panjang, hal ini terjadi karena dosen hanya merespon inti dari pertanyaan mahasiswa dengan jelas tanpa bermaksud tidak santun atau merendahkan mitra tutur. Dalam situasi tersebut, mahasiswa sangat memahaminya sehingga mereka menerima tanpa ada ketersinggungan ataupun menimbulkan konflik. Lebih jelas dapat dilihat pada tuturan berikut:

M: Selamat sore pak

Hari ini bapak ada di kampus?

Saya mau bimbingan web nya pk".

D: Ada

M: Saya mau bimbingan web nya pk

D: Drjam 6an

$\mathrm{Ok}$ 
Vol. 3, No. 2, Juli 2019, 23

Available Online at https://ejournal.warmadewa.ac.id/index.php/kulturistik DOI: dx.doi.org/10.22225/kulturistik.3.2.1185

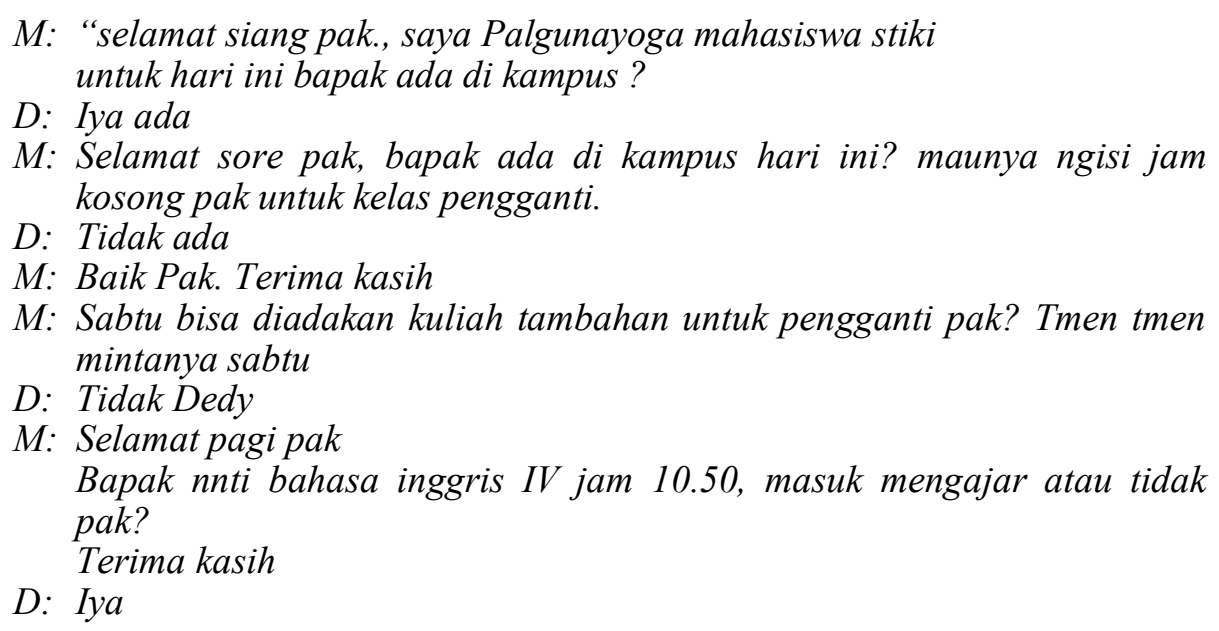

Pada data (a) dapat dilihat untuk merespon tuturan mahasiswa yang cukup panjang "... bapak ada di kampus?", dosen hanya menggunakan tuturan yang tegas, "ada". Kemudian pada data (b) ditemukan hal yang sama dimana dosen merespon dengan menjawab "Iya ada". Data (c) memperlihatkan dengan jelas sikap penerimaan mahasiswa atas respon jawaban dosen yang pendek dan tegas, "Tidak ada". Penerimaan mahasiswa dapat dilihat pada tuturan "Baik Pak, Terima kasih". Pada data (d) dan (e), temuan terlihat sama seperti pada tuturan (a) dan (b). Konteks semua tuturan tersebut jelas dosen hanya merespon inti dari pertanyaan mahasiswa tanpa bermaksud merendahkan mitra tutur dan mahasiswa sangat memahaminya sehingga mereka menerima tanpa ketersinggungan.

Scollon menyatakan ada tiga faktor yang mempengaruhi kesantunan ujaran, yaitu (1) Kekuasaan (power) yang artinya terdapat kecenderungan menaikkan tingkat kesantunan ujaran terhadap mitra tutur yang memiliki kekuasaan lebih tinggi dari penutur. (2) Jarak sosial (social distance) artinya semakin dekat atau akrab hubungan seseorang, semakin rendah tingkat kesantunan yang digunakan. Sebaliknya, semakin jauh kedekatan sebuah hubungan, semakin tinggi tingkat kesantunan yang digunakan. (3) Tingkat kepentingan (weight of imposition) artinya semakin tinggi tingkat kepentingan, maka semakin tidak langsung ujarannya. Lebih jelas dapat dilihat pada penjelasan di bawah.

\section{Kekuasaan (power)}

Perbedaan kekuasaan atau power antara penutur dan mitra tutur dapat dipengaruhi oleh usia, derajat atau status, dan pangkat serta jabatan. Pihak yang memiliki tingkat usia yang lebih dewasa atau memiliki pangkat dan jabatan yang lebih tinggi cenderung dianggap memiliki kedudukan atau power yang lebih tingi, sehingga terdapat semacam kebiasaan bahkan keharusan dari mitra tutur untuk bertutur santun. Amir (2004) menyatakan pada umumnya penutur Bahasa Indonesia memilih kesantunan yang tinggi saat bertutur dengan orang yang belum akrab dan lebih tinggi posisi kekuasaannya. Perhatikan data berikut!

a. "Selamat malam bu. Ini saya korti kelas K. Maaf bu, teman2 bertanya untuk spasi makalahnya itu kan 1.0 atau $1 \mathrm{~cm}$ bu? Terimakasi".

b. "Selamat malam buk, maaf mengganggu istirahatnya. Sya Sari Noviana dari 
Vol. 3, No. 2, Juli 2019, 24

Available Online at https://ejournal.warmadewa.ac.id/index.php/kulturistik DOI: dx.doi.org/10.22225/kulturistik.3.2.1185

kelas I. Untuk tugasnya bukan buat makalah, tapi harus ada covernya bu??. Terima kasih sebelumnya.".

c. "Selamat siang pak, maaf mengganggu, sya Gusti Nyoman Oka Wirawan nim 16101469 mau informasikan bahwa sya sudah mengumpulkan tugas 1 pem.web II di grup edmodo. Trims".

d. "Selamat sore pak, maaf mengganggu. Saya Siti, mahasiswi bapak di kelas $S$. Terkait tentang tugas yang di edmodo. Tugas 3 nya tentang apa ya pak? Minggu lalu seingat saya, bapak tidak ada memberikan tugas. ”.

Data (a), (b), (c), (d), dalam teks keempat data tersebut dapat dilihat bahwa mahasiswa menggunakan kata "maaf" dan "maaf mengganggu..." yang menunjukkan mereka berusaha memposisikan dirinya pada tingkat yang lebih rendah daripada dosen. Ungkapan-ungkapan itu juga bertujuan untuk menunjukkan rasa hormatnya kepada dosen dalam eksistensinya sebagai mahasiswa. Pada data (a) konteks dari interaksi tersebut terjadi ketika mahasiswa bertanya mengenai tugas makalah. Pada data tersebut mahasiswa menyampaikan “...teman2 bertanya..." yang menunjukkan dia menggunakan tuturan tidak langsung untuk menunjukkan kesantunannya.

\section{Jarak sosial (social distance)}

Pentingnya menjaga hubungan baik dan menjalin kedekatan emosional dengan dosen menjadi salah satu upaya dari mahasiswa untuk mencapai kesuksesan akademik. Oleh karena itu kebanyakan mahasiswa cenderung berusaha untuk dekat dengan dosennya. Akan tetapi tidak dapat dipungkiri untuk mencapainya diperlukan proses dan momentum dari kedua pihak sehingga akan terdapat dinamika kesantunan tuturan dari renggang hingga cukup dekat. Perhatikan data berikut!

a. "Selamat sore pak agus, saya dedy martawan dari koor SK C pagi, terima kasih".

b. "Selamat sore bapak saya korti dari kelas $G$ teknologi informasi pariwisata Terima kasih".

c. "Om swastiastu, selamat sore Pak Gandika

Saya mahasiswa stiki angkatan 2016

Nama : Putu Putri Yandayani

Nim : 16101022

Prodi : Ti-kab

Semester : 5

Saya mau bertanya, untuk tugas web ii terakhir dikumpul kapan pak?

Tolong diinfokan...

Terimakasih,

Selamat sore.".

d. "Assalamualaikum pak, maaf mengganggu,saya mau tanya pak mengenai tugas interview pedagang,itu termasuk dalam fungsi permintaan pak? terimakasih,".

e. "tugas nya perlu dikirim k email ibuk juga? apa print aja?”.

f. "Pas gladi pke baju ap? apa sama kyak yudisium?”.

g. "Kapan di laksanakannya kk makasih...".

h. "Buk saya bisanya besok kumpul, soalnya dikasih pinjem jasnya besok gmn buk?? Weiwei Wei". 
Vol. 3, No. 2, Juli 2019, 25

Available Online at https://ejournal.warmadewa.ac.id/index.php/kulturistik DOI: dx.doi.org/10.22225/kulturistik.3.2.1185

i. "Halu bu ini saya mau upload foto dri tadi gk bisa gimana donk?? Padahal saya sudah di coba terus... ukuran nya juga 1 mb tpi tetep aja gk mau buu... ".

Pada data (a) dan (b), konteks percakapan tersebut terjadi pada saat mahasiswa semester satu yang bertugas menjadi koordinator kelas menginformasikan nomor ponselnya kepada dosen setelah pertemuan perdana di kelas. Pada data tersebut menunjukkan mahasiswa menggunakan tuturan yang lebih santun kepada dosen yang baru saja dikenalnya karena hubungan keakraban yang belum terjalin setelah satu kali pertemuan. Hal ini menunjukkan adanya upaya dari penutur untuk bertutur santun kepada pihak yang jauh kedekatan hubungannya, sehingga semakin tinggi tingkat kesantunan yang digunakan. Sementara pada tuturan (c) dan (d), terlihat mahasiswa berusaha menunjukkan kedekatannya dengan menggunakan pendekatan religius berupa salam keagamaan "Om swastiastu,..." dan"Assalamualaikum pak..." walaupun mahasiswa belum mengenal dosen secara dekat sementara dia mengetahui agama sang dosen. Mahasiswa mencoba menggunakan komunikasi yang lebih efektif dengan membuka percakapan dengan salam-salam religius.

Pada data (e) menunjukkan percakapan tersebut terjadi antara mahasiswa yang sudah saling kenal dengan dosen dan sudah pernah berinteraksi sebelumnya sehingga tuturannya sedikit lebih santai dan terkesan akrab. Dalam konteks percakapan tersebut dosen tidak merasa tersinggung dan tidak terjadi konflik antara kedua belah pihak. Hal tersebut membuktikan semakin dekat atau akrab jarak sosial antara penutur maka semakin rendah tingkat kesantunan yang digunakan, akan tetapi dalam konteks ini pembicara tetap saling menghormati.

Pada data (f), (g), (h), dan (i) merupakan tuturan yang terjadi di grup media sosial facebook Halo STIKI saat seorang dosen mengunggah pengumuman dan mahasiswa bertanya lebih lanjut mengenai pengumuman tersebut. Dalam percakapan tersebut terlihat mahasiswa merasa sudah akrab dan dekat dengan dosen yang sudah biasa mengunggah pengumuman pada grup tersebut sehingga mahasiswa juga menggunakan tuturan yang terkesan akrab seperti pada teks data (f) "Pas gladi pke baju ap?" dan "apa sama kyak yudisium?". Bahkan pada data (g) mahasiswa dengan akrab memanggil sang dosen dengan sapaan "kk" pada teks "Kapan di laksanakannya kk makasih...". Oleh karena itu, jelas kita dapat mengukur jarak sosial penutur berdasarkan keakraban dengan mitra tuturnya. Semakin akrab tuturan antara penutur dan mitra tutur, maka semakin dekat jarak sosialnya. Sebaliknya, semakin tidak akrab tuturan antara penutur dan mitra tutur, semakin lebar jarak sosialnya.

\section{Tingkat kepentingan (weight of imposition)}

Dalam proses perkuliahan maupun kehidupan kampus tentu sangat banyak kepentingan dan kebutuhan dari mahasiswa untuk berkomunikasi dan berinteraksi dengan dosen. Untuk tercapainya kepentingan tersebut menjadi motivasi mahasiswa untuk selalu menjaga hubungan baik dengan dosen termasuk dengan menjaga tutur kata. Oleh karena itu semakin tinggi tingkat kepentingannya semakin tidak langsung dan santun tutuannya. Lebih jelas dapat dilihat pada data berikut.

a. "Selamat sore bu, maaf mengganggu Saya Suar mahasiswa kelas B Kewirausahaan hari Selasa. Saya blm masuk group wa sama edmono bu, saya mau minta kode edmodonya bu. Terimakasih". 
Vol. 3, No. 2, Juli 2019, 26

Available Online at https://ejournal.warmadewa.ac.id/index.php/kulturistik DOI: dx.doi.org/10.22225/kulturistik.3.2.1185

b. "Selamat malam pak

Maaf mengganggu waktunya

Saya mahasiswa angkatan 2017

Nama : Haritcha

Nim: 17101849

Saya mahasiswa yang mengikuti kelas pemrograman web 2 di kelas bapak. Apakah saya bisa minta kode grub di edmodo pak?

Terimakasih".

c. "Slmt mlm ibu,,ini sama Ambrosius Sapu,, Nim:18101162

Sy mau nanya nc,,pasword edmodo brapa ya Bu..?".

d. "Selamat pagi pak maaf mengganggu, saya rina Novita Yanti kelas Z ti kab malam, minta tolong accept permintaan Edmodo sya, agar bisa untuk mengirim tugas, terima kasih".

e. "selamat siang pak., saya Palgunayoga mahasiswa stiki untuk hari ini bapak ada di kampus?

saya mau bimbingan seminar pak".

f. "Selamat malam buk, saya ni putu indah risma dewi dari matakuliah aplikasi akuntansi kelas B. Saya mau tanya untuk nyusul uasnya kapan ya buk?".

g. "Pak Wahyu Wijaya Saya ada kerja diluar kota dari tgl 3 sampai tgl pak dan tgl 8 oktober baru balik kebali. Apakah ada kebijakan?".

h. "Selamat siang bu, saya I Gede Ananda Dwi Saputra dengan Nim 18101198 Kelas D, nnti saya dapat mata kuliah ibu pada jam 12.20 kan bu, saya ijin agak telat bu, soalnya masih ada kegiatan upacara agama dirumah butrimakasih bu..".

i. "Selamat pagi pak, saya I Gusti Ngurah Meiga Arya dari Kelas D, pak saya mau minta ijin tidak hadir saat matakuliah bapak karena saya ada upacara potong gigi pak, terima kasih pak selamat pagi”.

Pada data (a), (b), (c) dan (d) adanya kepentingan mahasiswa terhadap portal Edomo sehingga mahasiswa berusaha untuk bertutur santun untuk menginghindari terjadinya konflik yang mengganggu dan menghambat pencapaian kepentingannya. Pada data (e) terlihat pada teks "... saya mau bimbingan seminar ..." adanya kepentingan mahasiswa untuk dapat bertemu dan melaksanakan kegiatan bimbingan tugas akhir pada sang dosen menjadi motivasi mahasiswa untuk bertutur santun kepada dosen. Data (f) dan (g) menunjukkan adanya kepentingan mahasiswa untuk dapat melaksanakan ujian susulan. Kemudian pada data (h) dan (i) menunjukkan kepetingan mahasiswa untuk memperoleh ijin dari sang dosen sehingga berusaha bertutur santun dengan tujuan dapat meredam situasi dan mencegah konflik.

\section{SKALA KESANTUNAN}

Dalam menentukan skala kesantunan tuturan mahasiswa kepada dosen di media sosial, diaplikasikan Skala Likert dengan lima item skor, yaitu (1) sangat tidak santun, (2) tidak santun, (3) sedang, (2) santun (1) sangat santun. Wawancara dilakukan kepada 50 orang responden dosen di kampus STMIK STIKOM Indonesia selama dua semester (ganjil dan genap). Dari hasil 
Vol. 3, No. 2, Juli 2019, 27

Available Online at https://ejournal.warmadewa.ac.id/index.php/kulturistik DOI: dx.doi.org/10.22225/kulturistik.3.2.1185

wawancara tersebut didapatkan data rangkuman hasil penilaian seperti pada tabel berikut.

Tabel 1 Rangkuman Hasil Penilaian

\begin{tabular}{llll}
\hline No & Kategori & Kumulatif & Persentase \\
\hline 1. & Sangat santun & 13 & $46 \%$ \\
2. & Santun & 10 & $20 \%$ \\
3. & Sedang & 23 & $26 \%$ \\
4 & Tidak santun & - & \\
5 & Sangat tidak santun & - & \\
6 & Tidak menjawab & 4 & $8 \%$ \\
\hline
\end{tabular}

Untuk mendapatkan total skor terlebih dahulu mengalikan total jumlah responden yang memilih (T) dengan pilihan angka skor Likert (Pn). Sehingga dengan rumus T X Pn diperoleh seperti pada tabel berikut.

Tabel 2 Menghitung Total Skor

\begin{tabular}{lllll}
\hline No & Kategori & $\begin{array}{l}\text { Jumlah } \\
\text { responden }\end{array}$ & Skor & Jumlah \\
\hline 1. & Sangat santun & 13 & 5 & 65 \\
2. & Santun & 10 & 4 & 40 \\
3. & Sedang & 23 & 3 & 69 \\
4 & Tidak santun & - & 2 & 0 \\
5 & Sangat tidak santun & - & 1 & 0 \\
& Total & 46 & & 174 \\
\hline
\end{tabular}

Selanjutnya, untuk mendapatkan hasil interpretasi skor perhitungan, terlebih dahulu ditentukan skor tertinggi $(\mathrm{X})$ dan skor terendah $(\mathrm{Y})$ dengan rumus

$\mathrm{X}=$ skor tertinggi Likert $\mathrm{X}$ jumlah responden

$\mathrm{Y}=$ skor terendah Likert $\mathrm{X}$ jumlah responden

Perhitungannya dapat dilihat seperti di bawah ini:

$$
\begin{aligned}
& \mathrm{X}=5 \times 50 \\
& \mathrm{Y}=1 \text { X } 50
\end{aligned}
$$

Maka diperolah jumlah skor tertinggi untuk kategori "sangat santun" adalah sebesar 250 dan jumlah skor terendah untuk kategori "sangat tidak santun" sebesar 50. Selanjutnya, Interval jarak dari skala terendah $(0 \%)$ hingga tertinggi $(100 \%)$ adalah 20 . Sehingga kriteria interpretasi skor berdasarkan interval adalah

\begin{tabular}{|c|c|c|}
\hline No & Kategori & Interpretasi skor \\
\hline 1. & $\begin{array}{l}\text { Sangat santun } \\
\end{array}$ & $80 \%-100 \%$ \\
\hline 2. & Santun & $60 \%-79,99 \%$ \\
\hline 3. & Sedang & $40 \%-59,99 \%$ \\
\hline 4 & Tidak santun & $20 \%-39,99 \%$ \\
\hline 5 & Sangat tidak santun & $0 \%-19,99 \%$ \\
\hline
\end{tabular}
dapat dilihat pada tabel berikut: 
Vol. 3, No. 2, Juli 2019, 28

Available Online at https://ejournal.warmadewa.ac.id/index.php/kulturistik DOI: dx.doi.org/10.22225/kulturistik.3.2.1185

Hasil akhir didapatkan dengan rumus "total skor dibagi skor tertinggi (X)

dikalikan 100". Perhitungannnya dapat dilihat seperti berikut:

Skala kesantunan $=174 / 250 \times 100$

Skala kesantunan $=69,6 \%$ (berada pada kategori santun)

Dengan demikian, berdasarkan penilaian dari para responden, skala kesantunan mahasiswa termasuk dalam kategori "Santun".

Berdasarkan hasil analisis menggunakan skala Guttman, sebanyak 36 orang dari 50 orang responden atau sebesar $72 \%$ menyatakan diperlukan ketentuan yang mengatur tata cara mahasiswa berkomunikasi kepada dosen di media sosial. Sementara itu, sebanyak 6 orang responden atau sebesar $12 \%$ menyatakan tidak perlu, dan sebanyak 8 responden atau $16 \%$ tidak menjawab.

\section{SIMPULAN}

Dari hasil analisis terhadap kesantunan bahasa teks di media sosial dalam komunikasi mahasiswa kepada dosen STMIK STIKOM Indonesia, diperoleh simpulan sebagai berikut. Pola kesantunan bahasa teks percakapan di media sosial dari mahasiswa kepada dosen di STMIK STIKOM Indonesia Denpasar berhubungan erat dengan kegiatan perkuliahan dan kehidupan kampus. Polanya dikategorikan dalam sepuluh (10) macam, yaitu: (1) penjelasan mengenai tugas perkuliahan, (2) konsultasi urusan kemahasiswaan, (3) permohonan ijin kehadiran dan kedatangan, (4) konfirmasi kehadiran dosen, (5) menginformasikan waktu kuliah, (6) memberitahukan nomor ponsel, (7) permintaan waktu bimbingan, (8) kuliah tambahan atau hari pengganti, (9) modul dan sarana belajar, (10) konfirmasi mengenai ujian.

Perbedaan usia, derajat, dan kekuasaan antara mahasiswa dan dosen mempengaruhi maksim kesantunan yang digunakan dalam proses komunikasi. Mahasiswa memilih dan menyampaikan tuturan yang santun untuk memposisikan diri lebih rendah. Jika dikaitkan dengan teori Leech, dari keenam maksim yang ada ditemukan bahwa mahasiswa STMIK STIKOM Indonesia cenderung menggunakan Maksim Kebijaksanaan dan Maksim Kedermawanan/Penerimaan dalam tuturannya. Sementara itu, berdasarkan teori Scollon, ditemukan tiga faktor yang mempengaruhi kesantunan tuturan, yaitu (1) Kekuasaan (power), (2) Jarak sosial (social distance), (3) Tingkat kepentingan (weight of imposition) memang menjadi motivasi mahasiswa untuk memilih tuturan yang santun.

Berdasarkan penilaian dari para responden yang dianalisis menggunakan Skala Likert ditemukan bahwa skala kesantunan mahasiswa termasuk dalam kategori "Santun". Akan tetapi, meskipun tuturan mahasiswa berada pada kategori santun, berdasarkan analisis menggunakan Skala Guttman dominan (sebesar $72 \%$ ) dosen menginginkan adanya ketentuan yang mengatur tata cara mahasiswa berkomunikasi kepada dosen di media sosial.

\section{DAFTAR PUSTAKA}

Amir, A. (2004). Pembelajaran kesantunan berbahasa. Jurnal Bahasa Dan Seni.

Budiarta, I. W., \& Rajistha, I. G. N. A. (2018). Politemess In "Adit dan Sopo Jarwo" Animation. Lingua Cultura, 12(1), 25-30. https://doi.org/ doi.org/10.21512/lc.v12i1.1822

Fitriah, \& Hidayat, D. (2018). Politeness: Cultural Dimensions Of Linguistic Choice. Indonesian Journal of English Education, 5(1), 27-34.

Kamlasi, I. (2017). The Positive Politeness in Conversations Performed by the 


\section{Sulliturisistilk \\ KULTURISTIK JURNAL BAHASA \& BUDAYA}

Vol. 3, No. 2, Juli 2019, 29

Available Online at https://ejournal.warmadewa.ac.id/index.php/kulturistik DOI: dx.doi.org/10.22225/kulturistik.3.2.1185

Students of English Study Program of Timor University. METATHESIS, 1 (2), 68-81.

Mahmud, M. (2019). The use of politeness strategies in the classroom context by English university students. Indonesian Journal of Applied Linguistics, 8(3), 597-606. https://doi.org/10.17509/ijal.v8i3.15258

Ngalim, A. (2013). Sosiolinguistik: Suatu Kajian Fungsional dan Analisisnya. Solo: PBSID FKIP UMS.

Oka, M. D. D. (2011). The Principles of Pragmatics (Terjemahan). Jakarta: Universitas Indonesia.

Scollon. (1995). Intercultural Communication: Discourse Approach. Cambridge: Blackwell.

Sutopo. (2006). Metode Penelitian Kualitatif. Surakarta: Universitas Sebelas Maret.

Tretyakova, T. P. (2016). On Politeness in Translation. Journal of Siberian Federal University, Humanities \& Social Sciences 3, 597-606.

Wardhono, A. (2013). An Analysis On Politenesss In SMS Of The Students To The Lecturers Of English Department UNIROW Tuban. Didaktika, 19(2), 71-80. 